\title{
Quantitative measures of estrogen receptor expression in relation to breast cancer-specific mortality risk among white women and black women
}

\author{
Huiyan Ma ${ }^{1 *}$, Yani Lu', Polly A Marchbanks², Suzanne G Folger², Brian L Strom³ ${ }^{3}$ Jill A McDonald², \\ Michael S Simon ${ }^{4}$, Linda K Weiss ${ }^{5}$, Kathleen E Malone ${ }^{6}$, Ronald T Burkman', Jane Sullivan-Halley ${ }^{1}$, \\ Dennis M Deapen ${ }^{8}$, Michael F Press ${ }^{9}$ and Leslie Bernstein ${ }^{1}$
}

\begin{abstract}
Introduction: The association of breast cancer patients' mortality with estrogen receptor (ER) status (ER + versus ER-) has been well studied. However, little attention has been paid to the relationship between the quantitative measures of ER expression and mortality.

Methods: We evaluated the association between semi-quantitative, immunohistochemical staining of ER in formalinfixed paraffin-embedded breast carcinomas and breast cancer-specific mortality risk in an observational cohort of invasive breast cancer in 681 white women and 523 black women ages 35-64 years at first diagnosis of invasive breast cancer, who were followed for a median of 10 years. The quantitative measures of ER examined here included the percentage of tumor cell nuclei positively stained for ER, ER Histo (H)-score, and a score based on an adaptation of an equation presented by Cuzick and colleagues, which combines weighted values of ER H-score, percentage of tumor cell nuclei positively stained for the progesterone receptor (PR) and human epidermal growth factor receptor 2 (HER2) results. This is referred to as the ER/PR/HER2 score.
\end{abstract}

Results: After controlling for age at diagnosis, race, study site, tumor stage, and histologic grade in multivariable Cox proportional hazards regression models, both percentage of tumor cell nuclei positively stained for ER $\left(P_{\text {trend }}=0.0003\right)$ and the ER H-score $\left(P_{\text {trend }}=0.0004\right)$ were inversely associated with breast cancer-specific mortality risk. The ER/PR/HER2 score was positively associated with breast cancer-specific mortality risk in women with ER + tumor $\left(P_{\text {trend }}=0.001\right)$. Analyses by race revealed that ER positivity was associated with reduced risk of breast cancer-specific mortality in white women and black women. The two quantitative measures for ER alone provided additional discrimination in breast cancer-specific mortality risk only among white women with ER + tumors (both $P_{\text {trend }} \leq 0.01$ ) while the ER/PR/HER2 score provided additional discrimination for both white women $\left(P_{\text {trend }}=0.01\right)$ and black women $\left(P_{\text {trend }}=0.03\right)$ with ER + tumors.

Conclusions: Our data support quantitative immunohistochemical measures of ER, especially the ER/PR/HER2 score, as a more precise predictor for breast cancer-specific mortality risk than a simple determination of ER positivity.

\footnotetext{
* Correspondence: hma@coh.org

'Division of Cancer Etiology, Department of Population Sciences, Beckman Research Institute, City of Hope, Duarte, CA 91010, USA Full list of author information is available at the end of the article
} 


\section{Introduction}

The estrogen receptor (ER), which was identified in the late 1960s, is a protein molecule located in the nuclei of hormone target cells [1]. ER contains a specific ligand binding domain to which only estrogen or closely related molecules can bind. The positivity of ER in breast cancer tissue was first considered a strong indicator of response to endocrine therapy in the early 1970s [2] and was first recognized as a prognostic factor in the late 1970s [3].

Historically, ER expression in breast tissue was quantified using ligand binding assays, such as the most commonly used dextran-coated charcoal (DCC) assay [4,5]. Ligand binding assays quantify the amount of ERs with unoccupied ligand binding domains (those that have not bound estrogen or a closely related molecule) by measuring the amount of radiolabeled specific binding of estradiol in tissue homogenates [6]. Since the development of monoclonal antibodies to ER in the 1980s, ligand binding assays have been gradually replaced by monoclonal assays that measure both unoccupied and occupied ERs $[7,8]$. There are two types of monoclonal assays: the quantitative enzyme immunoassay [7] and the semi-quantitative immunohistochemistry (IHC) assay [8,9].

The ease of performing an IHC assay on routinely prepared formalin-fixed paraffin-embedded tissue blocks, combined with the assay's ability to evaluate small tumor samples and to ensure that only tumor cells are assessed, has led to the IHC assay becoming the first choice for ER measurement in pathology. The lack of a standardized cutoff point for ER positivity has been a longstanding issue. However, in 2010 the joint panel of the American Society of Clinical Oncology and the College of American Pathologists published guidelines recommending that $\geq 1 \%$ of tumor nuclei positively stained for ER should be the cutoff point for ER positivity [10]. The panel also noted that few follow-up studies had been published assessing quantitative staining of ER in tissue as a prognostic indicator. In 2011 Cuzick and colleagues reported that, in the Arimidex, Tamoxifen, Alone or in Combination trial, the quantitative ER Histo $(\mathrm{H})$-score alone or in combination with three other markers (progesterone receptor (PR), human epidermal growth factor receptor 2 (HER2) and Ki-67) was associated with risk of distant recurrence in postmenopausal women who were diagnosed with ER-positive breast cancer [11].

Here we present results from an observational cohort study of white women and black women with invasive breast cancer in which two quantitative measures of ER alone and an adaptation of Cuzick's combined score, based on quantitative values of ER and PR, and HER2 status [11], were assessed to determine how they compare with each other and with ER status (positive versus negative) in predicting mortality risk.

\section{Methods}

\section{Study population and data collection}

The participants were breast cancer patients from Detroit and Los Angeles (LA) who participated in the Women's Contraceptive and Reproductive Experiences (CARE) Study, a population-based, case-control study designed to examine risk factors for invasive breast cancer among white women and black women [12]. The Women's CARE Study selected a stratified (by age group) random sample of women ages 35 to 64 years who were newly diagnosed with histologically confirmed, first primary invasive breast cancer (International Classification of Diseases for Oncology codes C50.0 to C50.9) between July 1994 and April 1998. Black women were oversampled to maximize their numbers in the study, and white women were sampled to provide approximately equal numbers of women in each 5 -year age group between 35 and 64 years. The Women's CARE Study recruited and interviewed 1,921 breast cancer patients from Detroit $(n=679)$ and LA $(n=1,242)$. These two study sites were selected to collect tumor tissue samples based on representative case participants in the Women's CARE Study and the ability to obtain tumor tissue samples. All participants provided written informed consent. The study protocol was approved by the Institutional Review Boards at the University of Southern California, the Karmanos Comprehensive Cancer Center, the Centers for Disease Control and Prevention, and the City of Hope.

\section{Assessment of biomarkers}

Formalin-fixed paraffin-embedded tumor blocks were successfully retrieved from pathology laboratories where diagnoses were made for 1,333 participating breast cancer patients (Detroit, $n=414$; LA, $n=919$ ), which was approximately $80 \%$ of those requested at each site. Tumor blocks were not requested for all patients from these two sites due to financial constraints. All tumor blocks were carefully reviewed and evaluated in MFP's pathology laboratory at University of Southern California.

We excluded 127 patients' samples because the tumor blocks contained only carcinoma in situ $(n=56)$ or no tumor tissue $(n=46)$; had insufficient tissue for assay $(n=3)$; contained only hematoxylin-and-eosin-stained tissue $(n=8)$; or had other problems that made the evaluation difficult $(n=14)$. The expression of ER was determined for the remaining 1,206 samples (Detroit, $n=367$; LA, $n=839$ ).

The expression of ER was determined using previously published IHC methods [13]. In brief, the ER IHC method involved heat-induced antigen retrieval $(\mathrm{pH}$ 6.0) with a sodium citrate buffer, the use of a commercially available anti-ER mouse monoclonal primary antibody (1D5, 1:50 dilution; Zymed, Inc., South San Francisco, CA, USA), a biotinylated secondary rabbit anti-mouse antibody (Zymed, 
Inc.) with horseradish peroxidase-labeled streptavidin (Zymed, Inc.), and detection with diaminobenzidine. Immunostaining results for ER were scored semi-quantitatively on the basis of the visually estimated percentage of positively stained tumor cell nuclei. The intensity of nuclear staining was scored for individual tumor cell nuclei as negative $(-)$ /no staining, staining weakly $(+)$, staining intermediately $(++)$, or staining strongly $(+++)$. A minimum of 100 tumor cells were scored with the percentage of tumor cell nuclei in each category recorded. The sum of three staining categories equates to the overall percentage of positively stained tumor cell nuclei. If $\geq 1 \%$ of tumor cell nuclei stained positively, the tissue sample was considered ERpositive. The ER H-score was calculated as a weighted sum of the intensity of IHC tumor cell nuclei as follows $[14,15]$ :

$$
\begin{gathered}
\text { ER H-score }=(\% \text { of positively stained tumor cell nuclei } \\
\quad \text { at weak intensity category } \times 1) \\
+(\% \text { of positively stained tumor cell } \\
\text { nuclei at intermediate intensity category } \times 2) \\
+(\% \text { of positively stained tumor cell nuclei at } \\
\text { strong intensity category } \times 3)
\end{gathered}
$$

IHC for PR and HER2 was also conducted in the same central pathology laboratory using methods that have been described previously [16]. PR expression was quantified as the percentage of tumor cell nuclei positively stained for PR. For HER2, no (0) or weak (1+) membrane protein immunostaining was considered low HER2 expression (HER2-); and moderate $(2+)$ or strong membrane protein immunostaining $(3+)$ was considered HER2 overexpression $(\mathrm{HER} 2+$ ) based on previously validated results from the same pathology laboratory comparing IHC with HER2 gene amplification measured by fluorescent in situ hybridization methods [17].

A combined score of the ER H-score with the percentage of tumor cell nuclei positively stained for PR and HER2 positivity was generated according to Cuzick's IHC4 equation [11]:

$$
\begin{gathered}
\mathrm{IHC} 4=94.7 \times\left[-0.100 \mathrm{ER}_{10}-0.079 \mathrm{PR}_{10}+0.586 \mathrm{HER} 2\right. \\
+0.240 \ln (1+10 \mathrm{Ki} 67)]
\end{gathered}
$$

We did not assay Ki67 so excluded that part of the equation. The variable $\mathrm{ER}_{10}$ was generated by dividing the ER $\mathrm{H}$-score by $30 ; \mathrm{PR}_{10}$ was calculated as the percentage of tumor cell nuclei positively stained for PR divided by 10; HER2 was scored as 0 if negative and as 1 if positive. The combined score is referred to as the ER/ PR/HER2 score in this article.

\section{Tumor characteristics}

The Women's CARE Study collected tumor stage, histologic grade, hormone receptor status, and other tumor characteristics from the Detroit and LA Surveillance
Epidemiology and End Results (SEER) cancer registries. We previously reported that the agreement between the centralized pathology laboratory classification and reported ER status in the SEER registry was substantial $(\kappa=0.70)$ [18]. Two women were missing information on the tumor stage and were excluded from the statistical analyses; the final sample size for this analysis was 1,204 women (race: 681 white, 523 black; tumor stage: 697 localized, 507 nonlocalized).

\section{Vital status follow-up}

Participants were followed annually for vital status, date of death and cause of death, using standard SEER follow-up procedures. Data on vital status for Detroit participants were available through 31 December 2004; patients in LA were followed through 31 December 2007.

\section{Statistical analysis}

Analyses were conducted using deaths due to breast cancer (International Classification of Diseases codes ICD9-174, ICD10-C50) as endpoints. Follow-up in days began with breast cancer diagnosis and ended with the woman's death due to breast cancer $(n=272)$, her death due to another cause $(n=63)$, or the end of the followup period $(n=869)$. We did not include deaths due to

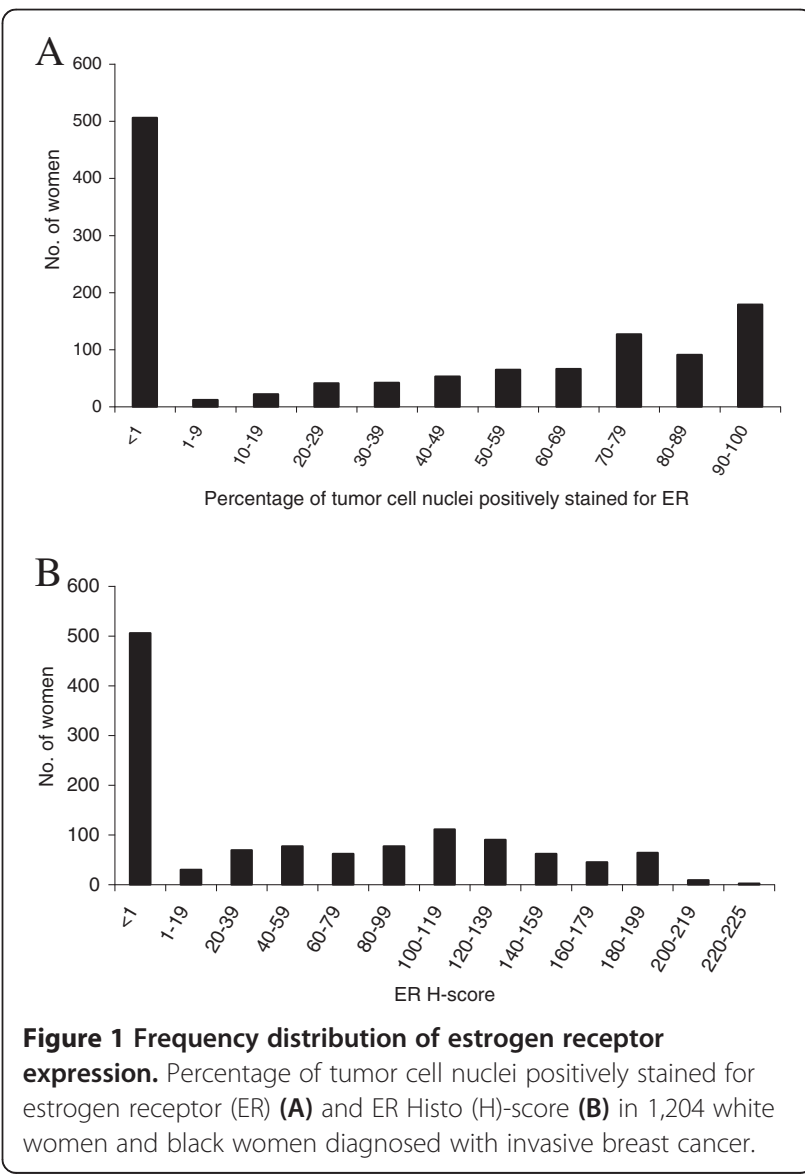


causes other than breast cancer as endpoints because we assumed that the quantity of ER expression would not be related to these deaths.

Multivariable Cox proportional hazards models were fit to the data to estimate the hazard ratio (HR) representing the relative risk of death due to breast cancer associated with an ER measure (percentage of tumor cell nuclei positively stained for ER, ER H-score, or the ER/ PR/HER2 score) and the 95\% confidence interval (CI) for the HR [19]. Models were fit to all data and by race (white, black). These models used age (in days) as the time metric, were stratified by age in years at diagnosis, and were adjusted for race, study site, and tumor stage (Model 1). A second analysis included additional adjustment for histologic grade (Model 2). The participants' frequency distributions for each of the covariates included in these models overall and by race have been described elsewhere [20]. We categorized the percentage of tumor cell nuclei positively stained for ER as a fivecategory variable ( $<1 \%, 1$ to $39 \%, 40$ to $59 \%, 60$ to $79 \%$, 80 to $100 \%$ ) and used previously published categories for the ER H-score [21]. We categorized the ER/PR/HER2 score for women diagnosed with ER-negative tumor and those with ER-positive tumor, separately. The combined score was categorized as a three-category variable $(<0$, $0,>0$ ) in women with ER-negative tumors since approximately $67 \%$ of them scored 0 . The combined score was categorized as a four-category variable according to quartile distribution of women with an ER-positive tumor. The association between the combined score and breast cancer-specific mortality risk was examined for women with ER-negative tumors and those with ER-positive tumors, respectively.

Tests for trend were conducted by fitting ordinal values corresponding to each category of the variable (percentage of tumor cell nuclei positively stained for ER, ER H-score, ER/PR/HER2 score) and determining whether the coefficient (slope of the dose response) differed statistically from 0 . We also obtained HRs (95\% CIs) associated with each $10 \%$ increase in tumor cell nuclei positively stained for ER and with each 20 unit increase in the ER H-score.

To test potential effect modification by race, we constructed a likelihood ratio test comparing two multivariable Cox proportional hazards models (likelihood ratio test for heterogeneity of HRs for dichotomous

Table 1 Descriptive statistics for the measures of estrogen receptor expression by follow-up outcome

\begin{tabular}{|c|c|c|c|c|c|}
\hline & \multirow[t]{2}{*}{ Overall } & \multicolumn{4}{|c|}{ Follow-up outcome } \\
\hline & & $\begin{array}{l}\text { Died from } \\
\text { breast cancer }\end{array}$ & $\begin{array}{l}\text { Died from } \\
\text { other causes }\end{array}$ & $\begin{array}{l}\text { Alive at the end } \\
\text { of follow-up }\end{array}$ & $P_{\text {F-test }}$ \\
\hline Overall & $n=1,204$ & $n=272$ & $n=63$ & $n=869$ & \\
\hline ER-positive $^{\mathrm{a}}(\%)$ & 58.0 & $42.5^{\mathrm{b}}$ & $67.0^{\mathrm{b}}$ & $61.8^{\mathrm{b}}$ & \\
\hline \multicolumn{6}{|l|}{ Among women with ER-positive ${ }^{a}$ tumor } \\
\hline$\%$ of tumor cell nuclei positively stained for ER & $64.7(25.5)$ & $62.2(27.0)$ & $65.6(24.5)$ & $65.1(25.2)$ & 0.53 \\
\hline ER H-score ${ }^{c}$ & $100.8(53.0)$ & $93.0(52.9)$ & $104.5(54.6)$ & $102.2(52.9)$ & 0.22 \\
\hline ER/PR/HER2 score ${ }^{d}$ & $-64.8(40.6)$ & $-49.9(43.5)$ & $-65.7(34.7)$ & $-67.9(39.8)$ & $<0.0001$ \\
\hline White women & $n=681$ & $n=131$ & $n=24$ & $n=526$ & \\
\hline ER-positive $(\%)$ & $62.5^{\mathrm{b}}$ & $47.2^{\mathrm{b}}$ & $78.6^{\mathrm{b}}$ & $65.8^{\mathrm{b}}$ & \\
\hline \multicolumn{6}{|l|}{ Among women with ER-positive ${ }^{a}$ tumor } \\
\hline$\%$ of tumor cell nuclei positively stained for ER & $64.6(25.9)$ & $58.0(27.4)$ & $74.4(18.1)$ & $65.2(25.7)$ & 0.03 \\
\hline ER H-score ${ }^{c}$ & $100.7(53.2)$ & $82.3(48.8)$ & $122.1(44.9)$ & $102.8(53.7)$ & 0.004 \\
\hline ER/PR/HER2 score ${ }^{d}$ & $-67.6(39.7)$ & $-46.1(44.7)$ & $-78.8(26.3)$ & $-70.8(38.2)$ & $<0.0001$ \\
\hline Black women & $n=523$ & $n=141$ & $n=39$ & $n=343$ & \\
\hline ER-positive $^{a}(\%)$ & $51.3^{\mathrm{b}}$ & $38.0^{\mathrm{b}}$ & $60.0^{\mathrm{b}}$ & $55.8^{\mathrm{b}}$ & \\
\hline \multicolumn{6}{|l|}{ Among women with ER-positive ${ }^{a}$ tumor } \\
\hline$\%$ of tumor cell nuclei positively stained for ER & $64.8(24.9)$ & $67.2(25.9)$ & $58.3(26.9)$ & $65.0(24.3)$ & 0.35 \\
\hline ER H-score ${ }^{c}$ & $100.9(52.8)$ & $105.5(55.2)$ & $90.0(58.4)$ & $101.0(51.5)$ & 0.50 \\
\hline ER/PR/HER2 score ${ }^{d}$ & $-60.3(41.8)$ & $-54.3(42.1)$ & $-54.8(37.4)$ & $-62.7(42.1)$ & 0.35 \\
\hline
\end{tabular}

Data presented as mean (standard deviation). ER, estrogen receptor; PR, progesterone receptor; HER2, human epidermal growth factor receptor 2.

${ }^{a}$ ER-positive, $\geq 1 \%$ positively stained tumor cell nuclei.

${ }^{\mathrm{b}}$ The distribution of age at diagnosis in each subgroup was adjusted according to the distribution of age at diagnosis among the 1,204 participants (35 to 39,40 to 44,45 to 49,50 to 54,55 to 59 , or 60 to 64 years).

${ }^{\mathrm{C}}$ ER Histo $(\mathrm{H})$-score $=(\%$ of positively stained tumor cell nuclei at weak intensity category $\times 1)+(\%$ of positively stained tumor cell nuclei at intermediate intensity category $\times 2)+(\%$ of positively stained tumor cell nuclei at strong intensity category $\times 3)$.

${ }^{\mathrm{d}}$ ER/PR/HER2 score $=94.7 \times\left(-0.100 \mathrm{ER}_{10}-0.079 \mathrm{PR}_{10}+0.586 \mathrm{HER} 2\right)$. 
Table 2 Breast cancer-specific mortality associated with percentage of tumor cell nuclei positively stained for estrogen receptor

\begin{tabular}{|c|c|c|c|c|}
\hline \multirow[t]{2}{*}{$\%$ of cells staining } & \multirow{2}{*}{$\begin{array}{l}\text { Number } \\
\text { of women }\end{array}$} & \multirow{2}{*}{$\begin{array}{l}\text { Number } \\
\text { of deaths }\end{array}$} & \multicolumn{2}{|c|}{ Adjusted HR $(95 \% \mathrm{Cl})$} \\
\hline & & & Model $1^{\mathrm{a}}$ & Model $2^{b}$ \\
\hline \multicolumn{5}{|l|}{ Overall } \\
\hline$<1$ (ER-negative) & 506 & 157 & Referent & Referent \\
\hline$\geq 1$ (ER-positive) & 698 & 115 & 0.53 (0.41 to 0.68$)$ & 0.64 (0.48 to 0.85$)$ \\
\hline 1 to 39 & 117 & 27 & 0.81 (0.53 to 1.24$)$ & 0.93 (0.60 to 1.43$)$ \\
\hline 40 to 59 & 118 & 18 & 0.55 (0.34 to 0.91$)$ & 0.66 (0.39 to 1.12$)$ \\
\hline 60 to 79 & 193 & 31 & $0.50(0.33$ to 0.74$)$ & 0.57 (0.38 to 0.88$)$ \\
\hline 80 to 100 & 270 & 39 & $0.43(0.30$ to 0.62$)$ & 0.52 (0.35 to 0.78$)$ \\
\hline Trend & & & $P_{\text {trend }}<0.0001$ & $P_{\text {trend }}=0.0003$ \\
\hline Trend in women with ER-positive tumors only & & & $P_{\text {trend }}=0.004$ & $P_{\text {trend }}=0.006$ \\
\hline Per $10 \%$ increase & & & 0.92 (0.89 to 0.95$)$ & 0.94 (0.91 to 0.97 ) \\
\hline Per $10 \%$ increase in women with ER-positive tumors only & & & 0.91 (0.84 to 0.99$)$ & 0.91 (0.84 to 0.99$)$ \\
\hline \multicolumn{5}{|l|}{ White women } \\
\hline$<1$ (ER-negative) & 251 & 69 & Referent & Referent \\
\hline$\geq 1$ (ER-positive) & 430 & 62 & 0.42 (0.29 to 0.61$)$ & 0.56 (0.36 to 0.87$)$ \\
\hline 1 to 39 & 75 & 18 & 0.81 (0.46 to 1.43$)$ & $1.04(0.57$ to 1.91$)$ \\
\hline 40 to 59 & 66 & 10 & $0.46(0.22$ to 0.94$)$ & 0.65 (0.30 to 1.43$)$ \\
\hline 60 to 79 & 123 & 17 & $0.37(0.21$ to 0.66$)$ & 0.47 (0.25 to 0.86$)$ \\
\hline 80 to 100 & 166 & 17 & $0.28(0.16$ to 0.50$)$ & 0.39 (0.21 to 0.73$)$ \\
\hline Trend & & & $P_{\text {trend }}<0.0001$ & $P_{\text {trend }}=0.0004$ \\
\hline Trend in women with ER-positive tumors only & & & $P_{\text {trend }}=0.001$ & $P_{\text {trend }}=0.002$ \\
\hline Per $10 \%$ increase & & & 0.88 (0.84 to 0.93$)$ & 0.91 (0.86 to 0.96$)$ \\
\hline Per $10 \%$ increase in women with ER-positive tumors only & & & 0.85 (0.76 to 0.96$)$ & 0.86 (0.76 to 0.96$)$ \\
\hline \multicolumn{5}{|l|}{ Black women } \\
\hline$<1$ (ER-negative) & 255 & 88 & Referent & Referent \\
\hline$\geq 1$ (ER-positive) & 268 & 53 & 0.56 (0.39 to 0.81$)$ & 0.62 (0.42 to 0.94$)$ \\
\hline 1 to 39 & 42 & 9 & $0.56(0.28$ to 1.15$)$ & $0.63(0.30$ to 1.29$)$ \\
\hline 40 to 59 & 52 & 8 & $0.50(0.24$ to 1.06$)$ & 0.55 (0.25 to 1.21$)$ \\
\hline 60 to 79 & 70 & 14 & $0.60(0.33$ to 1.08$)$ & $0.65(0.35$ to 1.21$)$ \\
\hline 80 to 100 & 104 & 22 & 0.56 (0.34 to 0.93$)$ & $0.64(0.37$ to 1.10$)$ \\
\hline Trend & & & $P_{\text {trend }}=0.007$ & $P_{\text {trend }}=0.06$ \\
\hline Trend in women with ER-positive tumors only & & & $P_{\text {trend }}=0.54$ & $P_{\text {trend }}=0.67$ \\
\hline Per $10 \%$ increase & & & $0.94(0.90$ to 0.98$)$ & 0.95 (0.91 to 1.00$)$ \\
\hline Per $10 \%$ increase in women with ER-positive tumors only & & & 0.98 (0.85 to 1.12$)$ & $1.00(0.87$ to 1.14$)$ \\
\hline \multicolumn{5}{|l|}{ Homogeneity between white women and black women } \\
\hline ER-positive versus ER-negative & & & $P_{\text {homogeneity }}=0.56$ & $P_{\text {homogeneity }}=0.55$ \\
\hline Trend & & & $P_{\text {homogeneity }}=0.13$ & $P_{\text {homogeneity }}=0.12$ \\
\hline Trend in women with ER-positive tumors only & & & $P_{\text {homogeneity }}=0.05$ & $P_{\text {homogeneity }}=0.02$ \\
\hline Per $10 \%$ increase & & & $P_{\text {homogeneity }}=0.16$ & $P_{\text {homogeneity }}=0.15$ \\
\hline Per $10 \%$ increase in women with ER-positive tumors only & & & $P_{\text {homogeneity }}=0.06$ & $P_{\text {homogeneity }}=0.02$ \\
\hline
\end{tabular}

$\mathrm{Cl}$, confidence interval; $\mathrm{ER}$, estrogen receptor; $\mathrm{HR}$, hazard ratio.

${ }^{a}$ Multivariable Cox proportional hazards regression models using age (in days) as the time metric stratified by age (in years) and adjusted for race (white, black),

study site (Detroit, Los Angeles), tumor stage (localized, non-localized).

${ }^{\mathrm{b}}$ Additionally adjusted for histologic grade (low, intermediate, high). 
variable (ER-positive vs. ER-negative), HRs for trends, HRs for per $10 \%$ increase in tumor cell nuclei positively stained for ER, or HRs for per 20 unit increase in ER H-score, with 1 degree of freedom) [22].

All reported $P$ values are two-sided. All statistical analyses were performed using SAS version 9.2 software (SAS Institute, Cary, NC, USA).

\section{Results}

Descriptive characteristics of ER expression overall and by follow-up outcome

The frequency distributions of the percentage of tumor cell nuclei positively stained for ER and ER H-score are shown in Figure 1A and B, respectively.

Of 1,204 women, 58\% were diagnosed with ER-positive ( $\geq 1 \%$ positively stained tumor cell nuclei) breast cancer (Table 1). The percentage of women with ER-positive breast cancer was lower among women who died from breast cancer $(42.5 \%)$ than among women who died from other causes $(67.0 \%)$ or among women who were alive at the end of the follow-up period (61.8\%). The differences across these three outcome groups were also observed by race. Further, black women were less likely to have ER-positive disease than white women (overall: 51.3\% vs. $62.5 \%)$.

Among all women with ER-positive breast cancer, the mean percentage of tumor cell nuclei positively stained for ER was $64.7 \%$, the mean ER $\mathrm{H}$-score was 100.8 , and the mean ER/PR/HER2 score was -64.8. The percentage of tumor cell nuclei positively stained for ER and the ER $\mathrm{H}$-score were, on average, lower among those who died from breast cancer than among those in other outcome groups in white women (both $P_{\mathrm{F} \text {-test }} \leq 0.03$ ), but not in black women (both $P_{\text {F-test }} \geq 0.35$ ). Women who died from breast cancer had a higher ER/PR/HER2 score than those in the other outcome groups in white women (mean ER/PR/HER2 score: $-46.1,-78.8,-70.8$ for three outcome groups, respectively; $P_{\text {F-test }}<0.0001$ ), but not in black women (mean ER/PR/HER2 score: -54.3, -54.8, 62.7 for three outcome groups, respectively; $P_{\mathrm{F} \text {-test }}=0.35$ ).

\section{Percentage of tumor cell nuclei positively stained for ER and breast cancer-specific mortality risk}

After controlling for age at diagnosis, race, study site, tumor stage, and histologic grade, we found that ERpositivity was associated with reduced risk of breast cancer-specific mortality (Table $2, \mathrm{HR}=0.64,95 \% \mathrm{CI}=$ 0.48 to 0.85 ). Further, the percentage of tumor cell nuclei positively stained for ER was inversely associated with breast cancer-specific mortality risk $\left(P_{\text {trend }}=0.0003\right.$, Figure 2A). Risk estimates for breast cancer-specific mortality decreased $6 \%$ ( $95 \% \mathrm{CI}=3$ to $9 \%$ ) for each $10 \%$ increase in the percentage of tumor cell nuclei positively stained for ER.

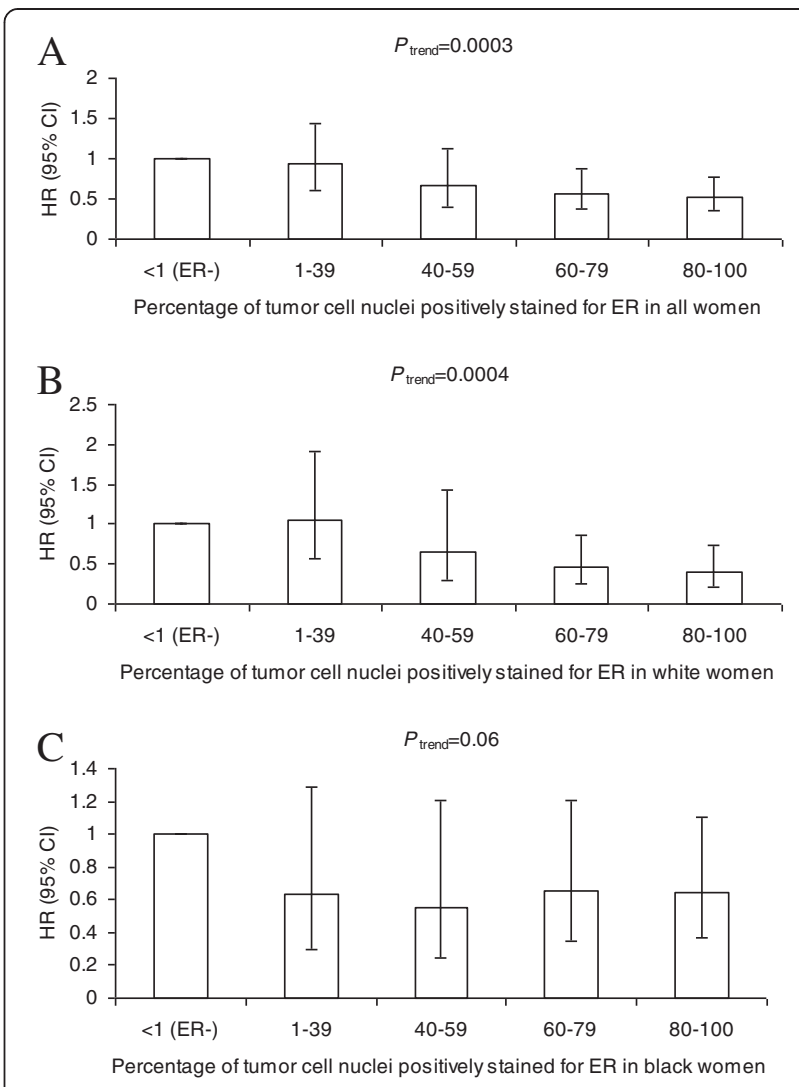

Figure 2 Percentage of tumor cell nuclei positively stained for estrogen receptor and breast cancer-specific mortality risk.

Adjusted hazard ratio (HR) estimates (95\% confidence intervals (Cls)) of breast cancer-specific mortality associated with the percentage of tumor cell nuclei positively stained for estrogen receptor (ER) in all women (A), in white women (B), and in black women $(\mathbf{C})$ with invasive breast cancer.

Analyses by race showed that ER-positivity was associated with reduced risk of breast cancer-specific mortality in whites and blacks (test for homogeneity of HRs for ERpositive vs. ER-negative from Model 2: $P=0.55$ ). However, the statistically significant inverse association between the percentage of tumor cell nuclei positively stained for ER and breast cancer-specific mortality risk was observed in white women $\left(P_{\text {trend }}=0.0004\right.$; Figure $\left.2 \mathrm{~B}\right)$, but not in black women $\left(P_{\text {trend }}=0.06\right.$; Figure $\left.2 \mathrm{C}\right)$. The trends in risk with increasing percentages of tumor cell nuclei positively stained for ER for whites and blacks did not differ statistically when both ER-positive and ER-negative women were studied (test for homogeneity of trends from Model 2: $P=0.12$ for trends using the categorical variable representation and $P=0.15$ for trends representing each $10 \%$ increase in tumor cell nuclei positively stained for ER), but were statistically different in the analyses restricted to women with ER-positive breast cancer (test for homogeneity of trends between white women and 
Table 3 Breast cancer-specific mortality associated with the estrogen receptor Histo-score

\begin{tabular}{|c|c|c|c|c|}
\hline \multirow[t]{2}{*}{ ER H-score ${ }^{a}$} & \multirow{2}{*}{$\begin{array}{l}\text { Number } \\
\text { of women }\end{array}$} & \multirow{2}{*}{$\begin{array}{l}\text { Number } \\
\text { of deaths }\end{array}$} & \multicolumn{2}{|c|}{ Adjusted HR (95\% Cl) } \\
\hline & & & Model $1^{\mathrm{b}}$ & Model $2^{c}$ \\
\hline \multicolumn{5}{|l|}{ Overall } \\
\hline$<1$ (ER-negative) & 506 & 157 & Referent & Referent \\
\hline 1 to 50 & 173 & 34 & 0.70 (0.48 to 1.03$)$ & $0.81(0.54$ to 1.21$)$ \\
\hline 51 to 100 & 173 & 31 & 0.58 (0.39 to 0.87$)$ & 0.68 (0.45 to 1.03$)$ \\
\hline 101 to 150 & 226 & 33 & 0.45 (0.31 to 0.67$)$ & 0.53 (0.35 to 0.81$)$ \\
\hline 151 to 225 & 126 & 17 & 0.39 (0.23 to 0.65$)$ & 0.48 (0.28 to 0.84$)$ \\
\hline Trend & & & $P_{\text {trend }}<0.0001$ & $P_{\text {trend }}=0.0004$ \\
\hline Trend in women with ER-positive tumors only & & & $P_{\text {trend }}=0.008$ & $P_{\text {trend }}=0.02$ \\
\hline Per 20 unit increase & & & 0.90 (0.86 to 0.94$)$ & 0.92 (0.88 to 0.97 ) \\
\hline Per 20 unit increase in women with ER-positive tumors only & & & 0.90 (0.83 to 0.98$)$ & 0.90 (0.84 to 0.99$)$ \\
\hline \multicolumn{5}{|l|}{ White women } \\
\hline$<1$ (ER-negative) & 251 & 69 & Referent & Referent \\
\hline 1 to 50 & 107 & 22 & 0.66 (0.39 to 1.11$)$ & 0.85 (0.48 to 1.52$)$ \\
\hline 51 to 100 & 104 & 17 & 0.46 (0.26 to 0.82$)$ & 0.59 (0.32 to 1.09$)$ \\
\hline 101 to 150 & 141 & 18 & 0.34 (0.19 to 0.58$)$ & 0.45 (0.24 to 0.83$)$ \\
\hline 151 to 225 & 78 & 5 & 0.20 (0.08 to 0.52$)$ & 0.29 (0.11 to 0.76$)$ \\
\hline Trend & & & $P_{\text {trend }}<0.0001$ & $P_{\text {trend }}=0.0006$ \\
\hline Trend in women with ER-positive tumors only & & & $P_{\text {trend }}=0.008$ & $P_{\text {trend }}=0.01$ \\
\hline Per 20 unit increase & & & 0.69 (0.59 to 0.79$)$ & 0.75 (0.64 to 0.88$)$ \\
\hline Per 20 unit increase in women with ER-positive tumors only & & & 0.66 (0.49 to 0.90$)$ & 0.68 (0.50 to 0.92$)$ \\
\hline \multicolumn{5}{|l|}{ Black women } \\
\hline$<1$ (ER-negative) & 255 & 88 & Referent & Referent \\
\hline 1 to 50 & 66 & 12 & 0.51 (0.27 to 0.94$)$ & $0.56(0.30$ to 1.06$)$ \\
\hline 51 to 100 & 69 & 14 & $0.66(0.36$ to 1.19$)$ & $0.72(0.39$ to 1.35$)$ \\
\hline 101 to 150 & 85 & 15 & 0.55 (0.31 to 0.99$)$ & $0.61(0.33$ to 1.11$)$ \\
\hline 151 to 225 & 48 & 12 & 0.54 (0.28 to 1.05$)$ & $0.64(0.32$ to 1.28$)$ \\
\hline Trend & & & $P_{\text {trend }}=0.008$ & $P_{\text {trend }}=0.07$ \\
\hline Trend in women with ER-positive tumors only & & & $P_{\text {trend }}=0.41$ & $P_{\text {trend }}=0.59$ \\
\hline Per 20 unit increase & & & 0.93 (0.88 to 0.98$)$ & $0.95(0.89$ to 1.01$)$ \\
\hline Per 20 unit increase in women with ER-positive tumors only & & & 0.96 (0.85 to 1.09$)$ & $0.97(0.86$ to 1.10$)$ \\
\hline \multicolumn{5}{|l|}{ Homogeneity between white women and black women } \\
\hline Trend & & & $P_{\text {homogeneity }}=0.10$ & $P_{\text {homogeneity }}=0.09$ \\
\hline Trend in women with ER-positive tumors only & & & $P_{\text {homogeneity }}=0.05$ & $P_{\text {homogeneity }}=0.02$ \\
\hline Per 20 unit increase & & & $P_{\text {homogeneity }}=0.08$ & $P_{\text {homogeneity }}=0.08$ \\
\hline Per 20 unit increase in women with ER-positive tumors only & & & $P_{\text {homogeneity }}=0.05$ & $P_{\text {homogeneity }}=0.02$ \\
\hline
\end{tabular}

$\mathrm{Cl}$, confidence interval; $\mathrm{ER}$, estrogen receptor; $\mathrm{HR}$, hazard ratio.

${ }^{\mathrm{a}}$ ER Histo-score $=(\%$ of cells stained at weak intensity category $\times 1)+(\%$ of cells stained at intermediate intensity category $\times 2)+(\%$ of cells stained at strong intensity category $\times 3$ ).

${ }^{\mathrm{b}}$ Multivariable Cox proportional hazards regression models using age (in days) as the time metric stratified by age (in years) and adjusted for race (white, black), study site (Detroit, Los Angeles), tumor stage (localized, non-localized).

${ }^{c}$ Additionally adjusted for histologic grade (low, intermediate, high).

black women from Model 2: $P=0.02$ for both trends using the categorical variable representation and trends representing each $10 \%$ increase in tumor cell nuclei positively stained for ER).

\section{Estrogen receptor Histo-score and breast cancer-specific mortality risk}

After controlling for age at diagnosis, race, study site, tumor stage, and histologic grade, we found that ER H- 
scores were inversely associated with breast cancerspecific mortality risk (Table 3, $P_{\text {trend }}=0.0004$; Figure 3A). Risk estimates for breast cancer-specific mortality decreased $8 \%$ (95\% CI $=3$ to $12 \%$ ) for each 20 unit increase in ER H-score.

Analyses by race showed that the statistically significant inverse association for white women $\left(P_{\text {trend }}=0.0006\right.$; Figure $3 \mathrm{~B})$, but not for black women $\left(P_{\text {trend }}=0.07\right.$; Figure $\left.3 \mathrm{C}\right)$. The difference between whites and blacks was not statistically significant when ER-positive and ER-negative women were included (test for homogeneity of trends from Model 2: $P=0.09$ for trends using the categorical variable representation and $P=0.08$ for trends representing each 20 unit increase in ER H-score), but it was statistically significant in analyses restricted to women with ER-positive breast cancer (test for homogeneity of trends between white women and black women from Model 2: $P=0.02$ for both trends using categorical variable representation and the trends representing each 20 unit increase in ER H-score).

ER/PR/HER2 score and breast cancer-specific mortality risk After controlling for age at diagnosis, race, study site, tumor stage, and histologic grade, no statistically signi-

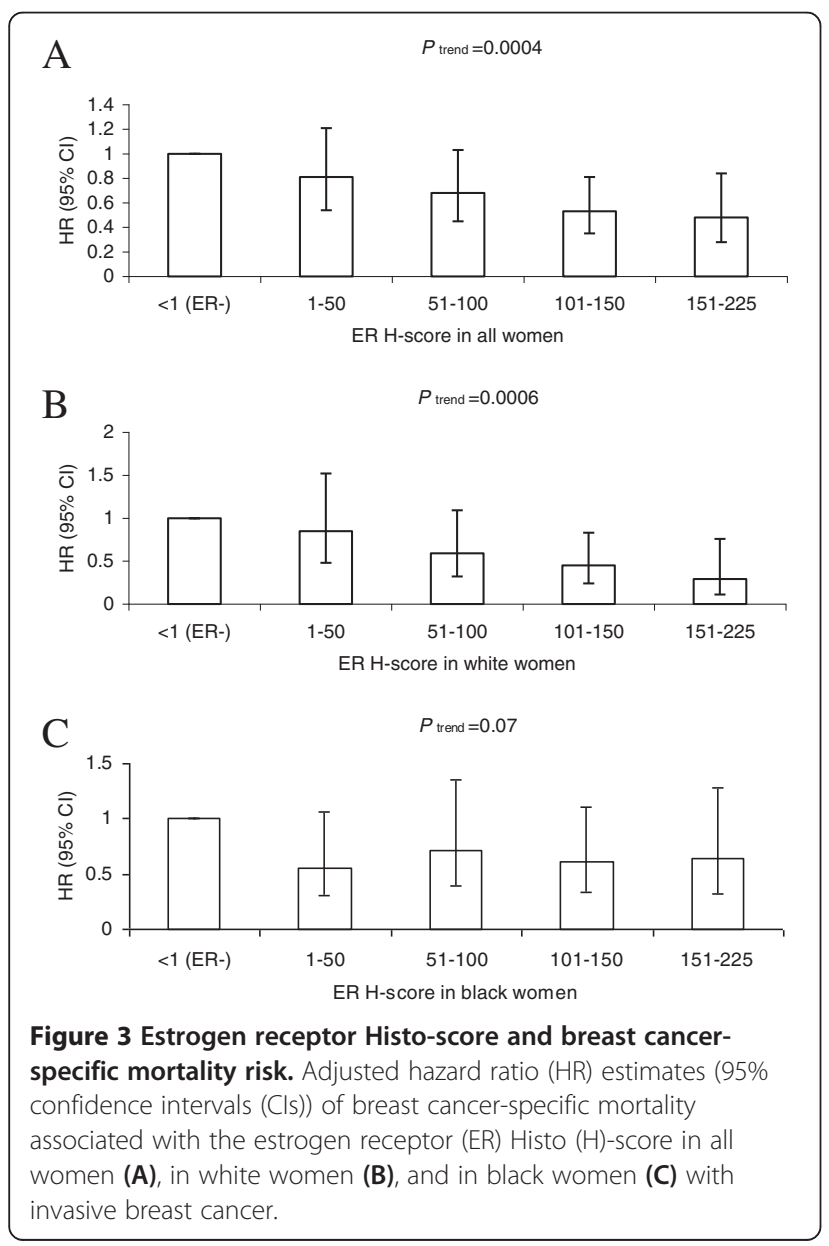

ficant association between the ER/PR/HER2 score and breast cancer-specific mortality risk was observed in women with ER-negative breast cancer (Table 4). However, in women with ER-positive tumors, the ER/PR/HER2 score was positively associated with breast cancer-specific mortality risk $\left(P_{\text {trend }}=0.001\right.$; Figure $\left.4 \mathrm{~A}\right)$; the HR for breast cancer death was $2.48(95 \% \mathrm{CI}=1.36$ to 4.55$)$ for those in the highest quartile of the ER/PR/HER2 score compared with those in the lowest quartile. The positive association was observed for both white women $\left(P_{\text {trend }}=0.01\right.$; Figure $4 \mathrm{~B})$ and black women $\left(P_{\text {trend }}=0.03\right.$; Figure $\left.4 \mathrm{C}\right)$ with ER-positive tumor.

\section{Discussion}

Our data showed that both the percentage of tumor cell nuclei positively stained for ER and the ER H-score were inversely associated with breast cancer-specific mortality risk in all women and among those with ER-positive breast cancer. The ER/PR/HER2 score was positively associated with breast cancer-specific mortality risk in women with ER-positive tumors. Analyses by race revealed that ER-positivity was associated with reduced risk of breast cancer-specific mortality in white women and black women. Both quantitative measures for ER alone provided additional discrimination in breast cancerspecific mortality risk for white women but not black women with ER-positive tumors, while the ER/PR/HER2 score provided the additional discrimination for both white women and black women with ER-positive tumors.

The association between the quantity of ER and patients' mortality risk or survival after diagnosis has been examined in six studies, three that used the DCC assay [23-25] and three that used the IHC assay [21,26,27]. The largest study using the DCC assay was conducted among 1,184 patients diagnosed with breast cancer between 1975 and 1981 who had a median follow-up of 5 years. This study found that increased concentration of ER in tissue homogenates was associated with increased probability of breast cancer-free survival, and this persisted after additional stratification of the data by lymph node status, tumor stage, and menopausal status [25].

Among the studies that used IHC, one reported that the relative risk for all-cause mortality, adjusted for tumor size and the percentage of nuclei stained for proliferation-related antigen, was 0.65 (95\% $\mathrm{CI}=0.30$ to 1.43) when comparing patients with $>10 \%$ with those with $\leq 10 \%$ of ER positively immunostained tumor cell nuclei and was 0.44 ( $95 \% \mathrm{CI}=0.21$ to 0.93 ) when comparing $>30 \%$ with those with $\leq 30 \%$ of ER [26]. This study was a small study with 180 primary breast cancer patients, who had between 4 and 7 years of clinical follow-up. Among 205 patients with ER-positive metastatic breast cancer (defined by DCC) who were followed 
Table 4 Breast cancer-specific mortality associated with the ER/PR/HER2 score

\begin{tabular}{|c|c|c|c|c|}
\hline \multirow[t]{2}{*}{ ER/PR/HER2 score ${ }^{a}$} & \multirow{2}{*}{$\begin{array}{l}\text { Number } \\
\text { of women }\end{array}$} & \multirow{2}{*}{$\begin{array}{l}\text { Number } \\
\text { of deaths }\end{array}$} & \multicolumn{2}{|c|}{ Adjusted HR $(95 \% \mathrm{Cl})$} \\
\hline & & & Model $1^{\mathrm{b}}$ & Model $2^{c}$ \\
\hline \multicolumn{5}{|c|}{ Women with ER-negative invasive breast cancer } \\
\hline \multicolumn{5}{|l|}{ Overall } \\
\hline$<0$ & 60 & 15 & Referent & Referent \\
\hline 0 & 337 & 103 & 1.32 (0.76 to 2.32$)$ & $1.30(0.74$ to 2.28$)$ \\
\hline$>0$ & 109 & 39 & 1.43 (0.77 to 2.69$)$ & 1.43 (0.76 to 2.67$)$ \\
\hline Trend & & & $P_{\text {trend }}=0.30$ & $P_{\text {trend }}=0.29$ \\
\hline \multicolumn{5}{|l|}{ White women } \\
\hline$<0$ & 35 & 9 & Referent & Referent \\
\hline 0 & 162 & 46 & $1.20(0.55$ to 2.62$)$ & 1.09 (0.48 to 2.45$)$ \\
\hline$>0$ & 54 & 14 & 1.16 (0.46 to 2.90$)$ & 1.09 (0.43 to 2.76$)$ \\
\hline Trend & & & $P_{\text {trend }}=0.79$ & $P_{\text {trend }}=0.88$ \\
\hline \multicolumn{5}{|l|}{ Black women } \\
\hline$<0$ & 25 & 6 & Referent & Referent \\
\hline 0 & 175 & 57 & 1.46 (0.59 to 3.61$)$ & 1.47 (0.60 to 3.64$)$ \\
\hline$>0$ & 55 & 25 & 1.57 (0.61 to 4.06$)$ & 1.55 (0.60 to 4.03$)$ \\
\hline Trend & & & $P_{\text {trend }}=0.42$ & $P_{\text {trend }}=0.45$ \\
\hline Homogeneity of tre & k women & & $P_{\text {homogeneity }}=0.36$ & $P_{\text {homogeneity }}=0.32$ \\
\hline \multicolumn{5}{|c|}{ Women with ER-positive invasive breast cancer } \\
\hline \multicolumn{5}{|c|}{ Quartiles of ER/PR/HER2 score ${ }^{d}$} \\
\hline \multicolumn{5}{|l|}{ Overall } \\
\hline Q1 & 175 & 18 & Referent & Referent \\
\hline Q2 & 177 & 22 & 1.27 (0.65 to 2.45$)$ & 1.39 (0.71 to 2.70$)$ \\
\hline Q3 & 172 & 33 & 2.04 (1.10 to 3.81$)$ & $2.00(1.07$ to 3.76$)$ \\
\hline Q4 & 174 & 42 & 2.71 (1.48 to 4.95$)$ & 2.48 (1.36 to 4.55$)$ \\
\hline Trend & & & $P_{\text {trend }}=0.0002$ & $P_{\text {trend }}=0.001$ \\
\hline \multicolumn{5}{|l|}{ White women } \\
\hline Q1 & 118 & 9 & Referent & Referent \\
\hline Q2 & 105 & 10 & 1.41 (0.53 to 3.74$)$ & 1.37 (0.52 to 3.62$)$ \\
\hline Q3 & 113 & 20 & 2.03 (0.84 to 4.92 ) & 1.98 (0.82 to 4.78$)$ \\
\hline Q4 & 94 & 23 & 2.77 (1.19 to 6.45$)$ & $2.62(1.12$ to 6.11$)$ \\
\hline Trend & & & $P_{\text {trend }}=0.01$ & $P_{\text {trend }}=0.01$ \\
\hline \multicolumn{5}{|l|}{ Black women } \\
\hline Q1 & 57 & 9 & Referent & Referent \\
\hline Q2 & 72 & 12 & $1.32(0.50$ to 3.51$)$ & 1.60 (0.58 to 4.45$)$ \\
\hline Q3 & 59 & 13 & 2.34 (0.85 to 6.42 ) & 2.34 (0.83 to 6.55$)$ \\
\hline Q4 & 80 & 19 & 3.43 (1.33 to 8.84$)$ & 2.88 (1.08 to 7.67$)$ \\
\hline Trend & & & $P_{\text {trend }}=0.006$ & $P_{\text {trend }}=0.03$ \\
\hline \multicolumn{3}{|c|}{ Homogeneity of trends between white women and black women } & $P_{\text {homogeneity }}=0.56$ & $P_{\text {homogeneity }}=0.32$ \\
\hline
\end{tabular}

$\mathrm{Cl}$, confidence interval; ER, estrogen receptor; HER2, human epidermal growth factor receptor 2; $\mathrm{HR}$, hazard ratio; PR, progesterone receptor.

${ }^{\mathrm{a} E R / P R / H E R 2}$ score $=94.7 \times\left(-0.100 \mathrm{ER}_{10}-0.079 \mathrm{PR}_{10}+0.586 \mathrm{HER} 2\right)$; the range of ER/PR/HER2 scores was -71.07 to 55.49 in women with ER-negative tumor and -141.10 to 53.92 in women with ER-positive tumor.

${ }^{\mathrm{b}}$ Multivariable Cox proportional hazards regression models using age (in days) as the time metric stratified by age (in years) and adjusted for race (white, black), study site (Detroit, Los Angeles), tumor stage (localized, non-localized).

'Additionally adjusted for histologic grade (low, intermediate, high); low and intermediate were combined into a single category in analyses for women with ER-negative tumors due to a small number of women with a low grade.

${ }^{d}$ Quartiles of ER/PR/HER2 scores in all women with ER-positive tumors were Q1 (-141.10 to -97.33), Q2 (-97.32 to -68.98), Q3 (-68.97 to -36.66), and Q4 (-36.65 to 53.92). 


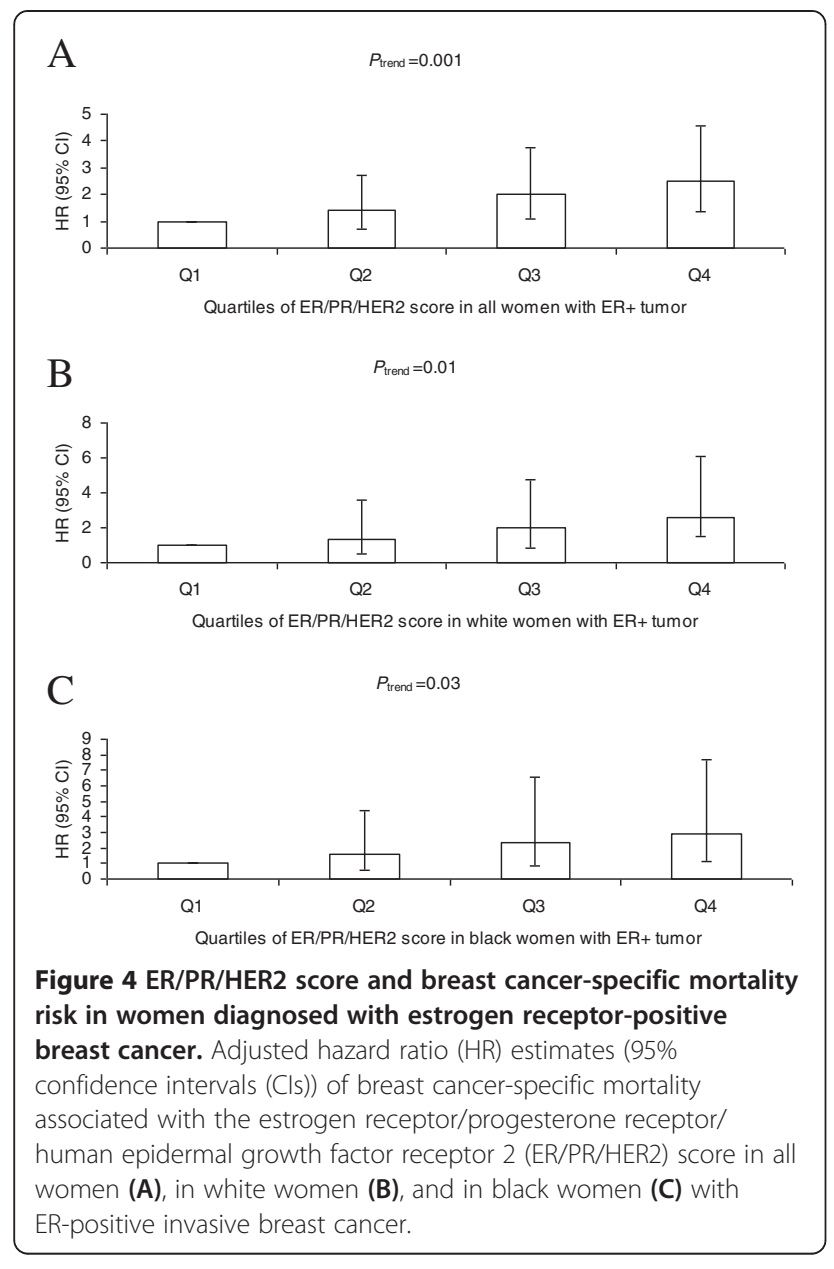

for a median of 9 years, the percentage of ER positively immunostained tumor cell nuclei was positively associated with the cumulative probability of survival [27]. Another study, which included 563 postmenopausal patients with stage I or stage II breast cancer, examined the relationships of the cumulative probability of survival with $\mathrm{H}$-score and with the percentage of tumor cell nuclei positive for ER [21]. These patients all received adjuvant tamoxifen, but no chemotherapy following surgical resection of histologically confirmed ER-positive breast cancer. The investigators reported that the cumulative probability of survival was positively associated with ER H-score (10-year survival: 41\%, 71\%, 67\%, and $84 \%$ for H-scores of $>0$ to 50,51 to 100,101 to 200 , and $>200$, respectively), but found no association with the percentage of tumor cells that had ER-positive nuclei (10-year survival: $65.5 \%, 43.4 \%$, and $70.9 \%$ for the percentage of cells staining for ER of $>0$ to $<34 \%$, 34 to $67 \%$, and $>67 \%$, respectively). All together, the previous studies, most of which were hospital based, provide some evidence that a higher level of ER expression in tumor tissue is associated with decreased mortality risk or better survival after breast cancer diagnosis. Our study using IHC, based on a larger population-based sample, found that the multivariableadjusted relative hazard for breast cancer-specific mortality decreased with increasing values of the two quantitative measures of ER alone.

The observed inverse association of breast cancerspecific mortality risk with increased quantity of ER may be due to the positive association between ER quantity and response to endocrine therapy [24,28]. Clinical trials have found that higher levels of ER expression in tumors were associated with a lower relative risk of recurrence $[29,30]$. Additionally, the inverse association may be related to the biological characteristics of breast cancers. Supporting evidence indicates that increasing recurrencefree survival is associated with higher ER expression even in patients who did not receive any adjuvant treatment [25]. Early studies reported an inverse association between the proliferation rate, determined by the thymidine labeling index, and ER content [31,32]. A higher thymidine labeling index was associated with unfavorable outcomes such as early relapse and shorter survival time [33].

It is unclear why the inverse associations between two quantitative measures of ER alone and breast cancerspecific mortality were observed in white women but not in black women with ER-positive breast cancer. It is important to note that the number of black women with ER-positive breast cancer is relatively small compared with white women with ER-positive breast cancer in our study sample. Further, if black women were less likely than white women to receive optimal treatment it is possible that we would not observe a decreasing risk of death with the percentage of tumor cell nuclei positively stained for ER or the ER H-score. Prior studies have suggested that black women may receive less optimal treatment than white women [34-37]. However, we were unable to assess treatment differences because treatment information was not collected.

Cuzick and colleagues reported that the combined score of ER H-score with PR/HER2/Ki-67 had prognostic value for the distant recurrence in postmenopausal women who were diagnosed with ER-positive breast cancer [11]. Similarly, our data, using an adaptation of Cuzick's score, showed that the ER/PR/HER2 score had prognostic value for breast cancer-specific mortality for both white women and black women with ER-positive tumors. Our data suggest that the weighted combination of ER/PR/HER2 score provides better prognostic discrimination for breast cancer-specific mortality risk among women with ERpositive tumors than that observed for quantitative measures of ER alone. Although Cuzick and colleagues also found that $\mathrm{Ki}-67$ provided prognostic information in addition to ER/PR/HER2 for the risk of the distance recurrence of breast cancer [11], we unfortunately did not assay Ki-67. Therefore, it would be valuable to assess the prog- 
nostic value of Ki-67 for breast cancer-specific mortality risk in the future studies.

\section{Conclusions}

Our data indicate that quantitative IHC measures of ER, especially the ER/PR/HER2 score, are more precise predictors for breast cancer-specific mortality risk than a simple determination of ER positivity.

\begin{abstract}
Abbreviations
CARE: Contraceptive and reproductive experiences; Cl: Confidence interval; DCC: Dextran-coated charcoal; ER: Estrogen receptor; HER2: Human epidermal growth factor receptor 2; HR: Hazard ratio; H-score: Histo-score; IHC: Immunohistochemistry; LA: Los Angeles; PR: Progesterone receptor; SEER: Surveillance epidemiology and end results.
\end{abstract}

\section{Competing interests}

The authors declare that they have no competing interests.

\section{Authors' contributions}

PAM, BLS, LKW, KEM, DMD, and LB conceived of and designed the Women's CARE Study. PAM, BLS, LKW, KEM, DMD, SGF, JAM, RTB, MSS, JS-H, and LB supervised or participated in the data collection and assembly of data of the Women's CARE Study. MSS, RTB and MFP helped to interpret medical questions during the conduct of the Women's CARE Study. MFP and LB conceived of and designed the pathology substudy. MFP conducted the assessment of biomarkers. HM conceived of the specific analytic questions investigated in this paper. $\mathrm{HM}$ and $\mathrm{YL}$ conducted data analyses under LB's supervision. HM interpreted the results and drafted the manuscript with LB's input. All authors participated in the critical revision of the manuscript and read and approved the final version.

\section{Acknowledgments}

The authors would like to thank Dr Karen Petrosyan, Armine Arakelyan, Hasmik Toumaian, and Judith Udove for technical assistance in the performance of the immunohistochemical assays for this study. They would also like to thank collaborators who contributed to the development and conduct of the Women's CARE Study but who did not directly contribute to the current study. This work was supported by National Institute for Child Health and Human Development grant NO1-HD-3-3175 and National Cancer Institute grant K05-CA136967. Data collection for the Women's CARE Study was supported by the National Institute of Child Health and Human Development and National Cancer Institute, NIH, through contracts with Emory University (N01-HD-3-3168), Fred Hutchinson Cancer Research Center (N01-HD-2-3166), Karmanos Cancer Institute at Wayne State University (N01-HD-3-3174), University of Pennsylvania (NO1-HD-3-3276), and University of Southern California (N01-HD-3-3175) and Interagency Agreement with Centers for Disease Control and Prevention (Y01-HD-7022). Collection of cancer incidence data in LA County by University of Southern California was supported by California Department of Health Services as part of statewide cancer reporting program mandated by California Health and Safety Code, Section 103885. Support for use of SEER cancer registries through contracts N01-CN-65064 (Detroit) and N01-PC-67010 (LA). Biomarker determination and analyses were supported by a contract from the National Institute of Child Health and Human Development (NO1-HD-3-3175) and a grant from the Breast Cancer Research Foundation (MFPress).

The findings and conclusions in this report are those of the authors and do not necessarily represent the official position of the Centers for Disease Control and Prevention.

\section{Author details}

'Division of Cancer Etiology, Department of Population Sciences, Beckman Research Institute, City of Hope, Duarte, CA 91010, USA. ${ }^{2}$ Division of Reproductive Health, Centers for Disease Control and Prevention, Atlanta, GA 30333, USA. ${ }^{3}$ Center for Clinical Epidemiology and Biostatistics, Department of Biostatistics and Epidemiology, University of Pennsylvania School of Medicine, Philadelphia, PA 19104, USA. ${ }^{4}$ Karmanos Cancer Institute, Department of Oncology, Wayne State University, Detroit, MI 48201, USA. ${ }^{5}$ Cancer Centers Branch, National Cancer Institute, Bethesda, MD 20892, USA.
${ }^{6}$ Division of Public Health Sciences, Fred Hutchinson Cancer Research Center, Seattle, WA 98109, USA. ${ }^{7}$ Department of Obstetrics and Gynecology, Baystate Medical Center, Springfield, MA 01199 , USA. ${ }^{8}$ Department of Preventive Medicine, University of Southern California, Los Angeles, CA 90033, USA. ${ }^{9}$ Department of Pathology, Keck School of Medicine, University of Southern California, Los Angeles, CA 90033, USA.

Received: 21 March 2013 Accepted: 30 August 2013

Published: 27 September 2013

\section{References}

1. Jensen EV: Estrogen receptor: ambiguities in the use of this term. Science 1968, 159:15.

2. MCGuire WL: Estrogen receptors in human breast cancer. J Clin Invest 1973, 52:73-77.

3. Knight WA, Livingston RB, Gregory EJ, McGuire WL: Estrogen receptor as an independent prognostic factor for early recurrence in breast cancer. Cancer Res 1977, 37:4669-4671.

4. Leclercq G, Heuson JC, Deboel MC, Mattheiem WH: Oestrogen receptors in breast cancer: a changing concept. Br Med J 1975, 1:185-189.

5. Leclercq G, Heuson JC, Schoenfeld R, Mattheiem WH, Tagnon HJ: Estrogen receptors in human breast cancer. Eur J Cancer 1973, 9:665-673.

6. Elwood JM, Godolphin W: Oestrogen receptors in breast tumours: associations with age, menopausal status and epidemiological and clinical features in 735 patients. Br J Cancer 1980, 42:635-644.

7. Nicholson RI, Colin P, Francis AB, Keshra R, Finlay P, Williams M, Elston CW, Blamey RW, Griffiths K: Evaluation of an enzyme immunoassay for estrogen receptors in human breast cancers. Cancer Res 1986, 46:4299s-4302s

8. King WJ, Greene GL: Monoclonal antibodies localize oestrogen receptor in the nuclei of target cells. Nat Geosci 1984, 307:745-747.

9. Shi SR, Chaiwun B, Young L, Cote RJ, Taylor CR: Antigen retrieval technique utilizing citrate buffer or urea solution for immunohistochemical demonstration of androgen receptor in formalin-fixed paraffin sections. J Histochem Cytochem 1993, 41:1599-1604.

10. Hammond ME, Hayes DF, Dowsett M, Allred DC, Hagerty KL, Badve S, Fitzgibbons PL, Francis G, Goldstein NS, Hayes M, Hicks DG, Lester S, Love R, Mangu PB, McShane L, Miller K, Osborne CK, Paik S, Perlmutter J, Rhodes A, Sasano H, Schwartz JN, Sweep FC, Taube S, Torlakovic EE, Valenstein P, Viale $G$, Visscher D, Wheeler T, Williams RB, et al: American Society of Clinical Oncology/College of American Pathologists guideline recommendations for immunohistochemical testing of estrogen and progesterone receptors in breast cancer (unabridged version). Arch Pathol Lab Med 2010, 134:e48-e72

11. Cuzick J, Dowsett M, Pineda S, Wale C, Salter J, Quinn E, Zabaglo L, Mallon E, Green AR, Ellis IO, Howell A, Buzdar AU, Forbes JF: Prognostic value of a combined estrogen receptor, progesterone receptor, Ki-67, and human epidermal growth factor receptor 2 immunohistochemical score and comparison with the Genomic Health recurrence score in early breast cancer. J Clin Oncol 2011, 29:4273-4278.

12. Marchbanks PA, McDonald JA, Wilson HG, Burnett NM, Daling JR, Bernstein L, Malone KE, Strom BL, Norman SA, Weiss LK, Liff JM, Wingo PA, Burkman RT, Folger SG, Berlin JA, Deapen DM, Ursin G, Coates RJ, Simon MS, Press MF, Spirtas R: The NICHD women's contraceptive and reproductive experiences study: methods and operational results. Ann Epidemiol 2002, 12:213-221.

13. Press MF: Estrogen and progesterone receptors in breast cancer. Adv Pathol Lab Med 1993, 6:117-148.

14. Kinsel LB, Szabo E, Greene GL, Konrath J, Leight GS, McCarty KS Jr: Immunocytochemical analysis of estrogen receptors as a predictor of prognosis in breast cancer patients: comparison with quantitative biochemical methods. Cancer Res 1989, 49:1052-1056.

15. McClelland RA, Finlay P, Walker KJ, Nicholson D, Robertson JF, Blamey RW, Nicholson Rl: Automated quantitation of immunocytochemically localized estrogen receptors in human breast cancer. Cancer Res 1990, 50:3545-3550

16. Ma H, Wang Y, Sullivan-Halley J, Weiss L, Marchbanks PA, Spirtas R, Ursin G, Burkman RT, Simon MS, Malone KE, Strom BL, McDonald JA, Press MF, Bernstein $L$ : Use of four biomarkers to evaluate the risk of breast cancer subtypes in the women's contraceptive and reproductive experiences study. Cancer Res 2010, 70:575-587. 
17. Press MF, Sauter G, Bernstein L, Villalobos IE, Mirlacher M, Zhou J-Y, Wardeh R, Li Y-T, Guzman R, Ma Y, Sullivan-Halley J, Santiago A, Park JM, Riva A, Slamon DJ: Diagnostic evaluation of HER-2 as a molecular target: an assessment of accuracy and reproducibility of laboratory testing in large, prospective, randomized clinical trials. Clin Cancer Res 2005, 11:6598-6607.

18. Ma H, Wang Y, Sullivan-Halley J, Weiss L, Burkman RT, Simon MS, Malone KE, Strom BL, Ursin G, Marchbanks PA, McDonald JA, Spirtas R, Press MF, Bernstein L: Breast cancer receptor status: do results from a centralized pathology laboratory agree with SEER registry reports? Cancer Epidemiol Biomarkers Prev 2009, 18:2214-2220.

19. Cox D, Oakes D: Analysis of Survival Data. London: Chapman \& Hall; 1984

20. Ma H, Lu Y, Malone KE, Marchbanks PA, Deapen DM, Spirtas R, Burkman RT, Strom BL, McDonald JA, Folger SG, Simon MS, Sullivan-Halley J, Press MF, Bernstein $L$ : Mortality risk of black women and white women with invasive breast cancer by hormone receptors, HER2, and p53 status. BMC Cancer 2013, 13:225

21. Morgan DA, Refalo NA, Cheung KL: Strength of ER-positivity in relation to survival in ER-positive breast cancer treated by adjuvant tamoxifen as sole systemic therapy. Breast 2011, 20:215-219.

22. Kleinbaum G, Kupper L, Morgestern H: Epidemiologic Research: Principles and Quantitative Methods. New York: Van Nostrand Reinhold; 1982.

23. Howat JM, Harris M, Swindell R, Barnes DM: The effect of oestrogen and progesterone receptors on recurrence and survival in patients with carcinoma of the breast. Br J Cancer 1985, 51:263-270.

24. Vollenweider-Zerargui L, Barrelet L, Wong Y, Lemarchand-Beraud T, Gomez F: The predictive value of estrogen and progesterone receptors' concentrations on the clinical behavior of breast cancer in women. Clinical correlation on 547 patients. Cancer 1986, 57:1171-1180.

25. Shek LL, Godolphin W: Survival with breast cancer: the importance of estrogen receptor quantity. Eur J Cancer Clin Oncol 1989, 25:243-250.

26. Lockwood CA, Ricciardelli C, Raymond WA, Seshadri R, McCaul K, Horsfall DJ: A simple index using video image analysis to predict disease outcome in primary breast cancer. Int J Cancer 1999, 84:203-208.

27. Elledge RM, Green S, Pugh R, Allred DC, Clark GM, Hill J, Ravdin P, Martino S, Osborne CK: Estrogen receptor (ER) and progesterone receptor (PgR), by ligand-binding assay compared with $\mathrm{ER}, \mathrm{PgR}$ and $\mathrm{pS} 2$, by immuno-histochemistry in predicting response to tamoxifen in metastatic breast cancer: a Southwest Oncology Group Study. Int J Cancer 2000, 89:111-117.

28. Byar DP, Sears ME, McGuire WL: Relationship between estrogen receptor values and clinical data in predicting the response to endocrine therapy for patients with advanced breast cancer. Eur J Cancer 1979, 15:299-310.

29. Bartlett JM, Brookes CL, Robson T, van de Velde CJ, Billingham $\amalg$, Campbell FM, Grant M, Hasenburg A, Hille ET, Kay C, Kieback DG, Putter H, Markopoulos C, Kranenbarg EM, Mallon EA, Dirix L, Seynaeve C, Rea D: Estrogen receptor and progesterone receptor as predictive biomarkers of response to endocrine therapy: a prospectively powered pathology study in the Tamoxifen and Exemestane Adjuvant Multinational trial. J Clin Oncol 2011, 29:1531-1538.

30. Dowsett M, Allred C, Knox J, Quinn E, Salter J, Wale C, Cuzick J, Houghton J,

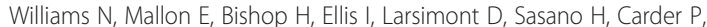
Cussac AL, Knox F, Speirs V, Forbes J, Buzdar A: Relationship between quantitative estrogen and progesterone receptor expression and human epidermal growth factor receptor 2 (HER-2) status with recurrence in the Arimidex, Tamoxifen, Alone or in Combination trial. J Clin Oncol 2008, 26:1059-1065.

31. Silverstrini R, Daidone MG, Di Fronzo G: Relationship between proliferative activity and estrogen receptors in breast cancer. Cancer 1979, 44:665-670.

32. Raber MN, Barlogie B, Latreille J, Bedrossian C, Fritsche H, Blumenschein G: Ploidy, proliferative activity and estrogen receptor content in human breast cancer. Cytometry 1982, 3:36-41.

33. Meyer JS, Lee JY: Relationships of S-phase fraction of breast carcinoma in relapse to duration of remission, estrogen receptor content, therapeutic responsiveness, and duration of survival. Cancer Res 1980, 40:1890-1896.

34. Gorin SS, Heck JE, Cheng B, Smith SJ: Delays in breast cancer diagnosis and treatment by racial/ethnic group. Arch Intern Med 2006 166:2244-2252.

35. Griggs JJ, Sorbero ME, Stark AT, Heininger SE, Dick AW: Racial disparity in the dose and dose intensity of breast cancer adjuvant chemotherapy. Breast Cancer Res Treat 2003, 81:21-31.
36. Du Xianglin L, Gor BJ: Racial disparities and trends in radiation therapy after breast-conserving surgery for early-stage breast cancer in women, 1992 to 2002. Ethnic Dis 2007, 17:122-128.

37. Hershman D, McBride R, Jacobson JS, Lamerato L, Roberts K, Grann VR, Neugut Al: Racial disparities in treatment and survival among women with early-stage breast cancer. J Clin Oncol 2005, 23:6639-6646.

doi:10.1186/bcr3486

Cite this article as: Ma et al:: Quantitative measures of estrogen receptor expression in relation to breast cancer-specific mortality risk among white women and black women. Breast Cancer Research 2013 15:R90

\section{Submit your next manuscript to BioMed Central and take full advantage of:}

- Convenient online submission

- Thorough peer review

- No space constraints or color figure charges

- Immediate publication on acceptance

- Inclusion in PubMed, CAS, Scopus and Google Scholar

- Research which is freely available for redistribution

Submit your manuscript at www.biomedcentral.com/submit
C) BioMed Central 